\title{
James Lind (1716-94) of Edinburgh and the treatment of scurvy
}

\author{
Peter M Dunn
}

The Lind family moved to Edinburgh from Ayrshire in the 16th century. James Lind (senior) married Margaret Smellum in 1707 and they had a daughter, Joan, nine years before their son James was born on 4 October 1716 .

James Lind received his schooling in Edinburgh before being apprenticed at the age of 15 in 1731 to George Langlands, a member of the Incorporation of Surgeons. After completing his training in 1739, he set off south and joined the Royal Navy as a surgeon's mate. The next nine years were spent voyaging in the Mediterranean, off West Africa, and in the West Indies. In those days ships were cold, damp, and unwholesome, while the food consisted of putrid beef, rancid pork, mouldy biscuit and foul water. During these years, Lind carefully recorded all his observations, as his later writings show. By 1747 he had been promoted surgeon to HMS Salisbury, and it was during her cruise in the English Channel that year that there was a severe outbreak of scurvy and he was able to carry out his classic experiments on its treatment. The following year Lind left the Navy and returned to Edinburgh where he acquired an $\mathrm{MD}$ by thesis and a license to practise in the city. This he did for the next 10 years. In 1750 he was elected a fellow of the Royal College of Physicians (Edinburgh) and seven years later became its treasurer. He also became a member of the Philosophical and Medical Society of Edinburgh.

In 1753 Lind published his classic Treatise on the Scurvy ${ }^{1}$ and dedicated it to Lord Anson, First Lord of the Admiralty, who as a commodore had sailed round the world in 1740 and knew all about the ravages of this disease. Indeed, of the 961 sailors manning his six ships, 626 were dead from scurvy by the time the fleet reached the Juan Fernandez Islands. Possibly because of Anson's influence, Lind left his Edinburgh practice in 1758 to take up an appointment as chief physician to the new Royal Naval (Haslar) Hospital at Portsmouth. His salary was $£ 200$ a year. There he saw hundreds of men with scurvy every day, because the Navy, urged on by Gilbert Blane, only implemented his recommendations on fruit juice the year after his death. As he wrote: "The province has been mine to deliver precepts; the power is in other to execute." Following the routine use of lemon juice in 1795, scurvy vir-

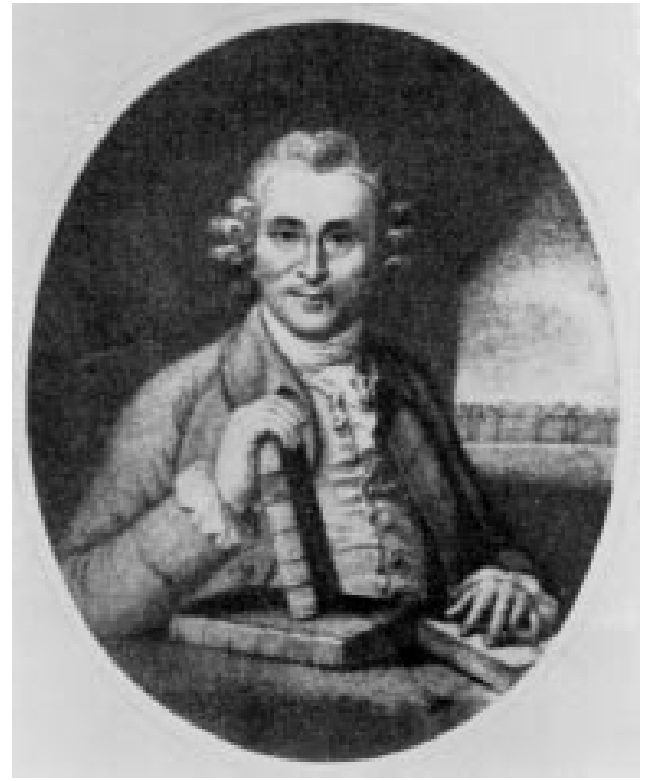

Dr Fames Lind 1716-94.

tually disappeared from the Navy, though more than 100 years were to pass before the disease was similarly banished on land.

Lind was a quiet unassuming man and an accurate observer, able to divest himself of preconceived ideas and reason to his way to logical conclusions. The following extract from his Treatise has a modern ring to it:

“... it is no easy matter to root out old prejudices, or to overturn opinions established by time, custom and great authorities ... Indeed, before this subject could be set in a clear and proper light, it was necessary to remove a great deal of rubbish ... Where I have been necessarily led, in this disagreeable part of the work, to criticise the sentiments of eminent and learned authors, I have not done it with a malignant view of depreciating their labours, or their names; but from a regard to truth, and to the good of mankind."

While scurvy had been known since ancient times and the value of fresh fruit suggested by John Woodall (1569-1643), it fell to Lind to record the natural history of the disease and to confirm by experiment how it might best be treated and, indeed, prevented. For, as he 
wrote: “. . a almost all diseases are easier prevented than removed."

\section{Controlled trial on the treatment of scurvy}

"On the 20th of May 1747, I selected twelve patients in the scurvy, on board the Salisbury at sea. Their cases were as similar as I could have them. They all in general had putrid gums, the spots and lassitude, with weakness of the knees. They lay together in one place, being a proper apartment for the sick in the fore-hold; and had one diet common to all, viz. water gruel sweetened with sugar in the morning; fresh mutton-broth often times for dinner; at other times light puddings, boiled biscuit with sugar, etc., and for supper, barley and raisins, rice and currants, sago and wine or the like. Two were ordered each a quart of cyder a day. Two others took twenty-five drops of elixir vitriol three times a day ... Two others took two spoonfuls of vinegar three times a day ... Two of the worst patients were put on a course of sea-water ... Two others had each two oranges and one lemon given them every day ... The two remaining patients, took ... an electary recommended by a hospital surgeon ... The consequence was, that the most sudden and visible good effects were perceived from the use of oranges and lemons; one of those who had taken them, being at the end of six days fit for duty . . . The other was the best recovered of any in his condition; and ... was appointed to attend the rest of the sick. Next to the oranges, I thought the cyder had the best effects ..."

Lind's clinical description of scurvy is also a classic:

"The first indication ... of this disease, is generally a change of colour in the face . . . to a pale and bloated look ... Their ... aversion to motion degenerates soon into an universal lassitude, with a stiffness and feebleness of the knees upon using exercise; with which they are apt to be much fatigued, and upon occasion subject to a breathlessness or panting. Their gums soon after becomes itchy, swell, and are apt to bleed upon the gentlest friction. Their breath is then offensive; and upon looking into their mouths, the gums appear of an unusual redness, are soft and spongy and ... putrid. They ... . are prone to fall into haemorrhages from other parts of the body. Their skin at this time feels dry . . . and when examined, it is found covered with several reddish, bluish, or rather black and livid spots . . a it were a bruise . . . Many have a swelling of their legs; which is first observed on their ancles towards the evening, and hardly to be seen next morning; but . . . it gradually advances up the leg, and the whole member becomes oedematous ..."

Although described by Glisson in 1650, scurvy in childhood was thought to be a complication of acute rickets until Thomas Barlow of London (1845-1945) identified it as a separate entity in 1893, and as being no different from adult scurvy. ${ }^{2}$ It remained for SzentGyörgyi of Hungary, working in Cambridge in 1932, to isolate l-ascorbic acid in 1928 and to show that it was the specific cure for scurvy.

Lind retired from Haslar Hospital after 25 years of service in 1783 . He had married Isobel Dickie in Edinburgh and was succeeded in the post by his son John. Besides his publications on scurvy, Lind published essays on fevers and infections (1763), on diseases incidental to Europeans in hot climates (1768), on jail distemper (1773), and on the most effectual means of preserving the health of seamen (1779). His recommendations contained a number of important and innovative ideas concerning hygiene, nutrition, the importance of fire and fumigation in combating infection, and on the destruction of clothing and bedding in order to prevent the spread of typhus.

In 1783 Lind became a Fellow of the Royal Society of Edinburgh. He died on 13 July 1794, at the age of 78 , two years before his wife, and was buried in Porchester Church. So passed a man of acute observation and independent thought. Deservedly, he is widely regarded as the first modern clinical investigator.

1 Lind J. A treatise on the scurvy. 3rd edn. London: S Crowder et al, 1772 .

2 Barlow T. On cases described as "acute rickets" which are possibly a combination of rickets and scurvy, the scurvy being essential and the rickets variable. Medico-Chirurgical Transactions 1883;66:159-220. 